\title{
SISTEM INFORMASI PENGGAJIAN KARYAWAN BERBASIS WEB MENGGUNAKAN FRAMEWORK LARAVEL
}

\author{
Rina Gustina $^{1}$, Henny Leidiyana ${ }^{2}$ \\ ${ }^{1,2}$ Program studi Teknik Informatika, STMIK Nusa Mandiri \\ Jln. Kramat Raya No. 18 Jakarta Pusat \\ ${ }^{1}$ rinagustina16@gmail.com \\ 2henny.hnl@nusamandiri.ac.id
}

\begin{abstract}
Abstrak - PT. Evershine Convertindo merupakan perusahaan yang bergerak dalam bidang Industri Kertas. Sistem yang ada hanya berupa berkas sederhana. Kelemahan dari sistem tersebut tidak efisien, banyak memakan waktu dalam pencatatan dan mengolah proses penggajian. Proses pencatatan dan perhitungan gaji yang diterapkan oleh perusahaan masih bersifat manual sehingga menyebabkan proses gaji sering terlambat. Dalam menyelesaikan masalah tersebut maka penulis merancang suatu sitem informasi penggajian karyawan. Dalam perancangan ini, penulis menggunakan bahasa pemrograman PHP dengan format database MySql, menggunakan Metode Waterfall dan menggunakan framework Laravel. Dengan rancangan sistem tersebut diharapkan perusahaan akan memperoleh beberapa kemudahan dalam menginput data sekaligus membantu pihak perusahaan untuk menyusun laporan penggajian menjadi lebih cepat dan lebih efisien.
\end{abstract}

Kata kunci: Penggajian Karyawan, PHP, MySql, Waterfall, Laravel

\section{Pendahuluan}

Website atau situs dapat diartikan sebagai kumpulan halaman yang menampilkan informasi data teks, data gambar diam atau gerak, data animasi, suara, atau gabungan dari semuanya, baik yang bersifat statis maupun dinamis membentuk satu rangkain bangunan saling terkait dimana masing-masing dihubungkan dengan jaringan halaman (Rusman \& Angraini, 2019).

Dalam pembuatan situs web ini penulis juga menerapkan metode MVC sebagai pilihan dalam pengembangan sistemnya. Model View Controller ( $M V C)$ untuk mengklasifikasikan pengkodean pada database, tampilan dan kontrol logika aplikasi untuk memfasilitasi pengembangan lebih lanjut dari pola yang telah ditetapkan (Dalis, Nurmah, \& Purwanto, 2019).

Pada saat ini informasi sangatlah penting bagi sebuah perusahaan. Informasi dari satu bagian saling terkait dengan bagian lainnya, sehingga informasi yang diberikan oleh suatu bagian sangat mempengaruhi aktivitas bagian yang lainnya. Informasi yang cepat tepat dan terintegrasi akan memperlancar proses pada bagian yang terkait yang dalam suatu perusahaan.

Gaji adalah suatu bentuk balas jasa ataupun penghargaan yang diberikan secara teratur kepada seorang karyawan atas jasa dan hasil kerjanya. Gaji sering juga disebut sebagai upah,dimana keduanya merupakan suatu bentuk kompensasi, yakni imbalan jasa yang diberikan secara teratur atas prestasi kerja yang diberikan kepada seorang karyawan (Eko, Eka, \& Gunawan, 2017).

Salah satu perusahaan kertas PT. Evershine Convertindo yang terletak di kabupaten bekasi yang bergerak pada bidang industri. Perkembangan zaman teknologi yang digunakan juga semakin berkembang, namun PT.Evershine Convertindo ada permasalahan dengan adanya perkembangan teknologi tersebut diantaranya sistem penggajian karyawan yang ada sekarang masih konvensional yaitu semua transaksi masih dicatat menggunakan secara manual, sehingga membuat proses pengerjaan harus dilakukan secara berulang-ulangdan memerlukan waktu yang lama (Mayasari, 2015).

Karena itu penulis merancang sistem informasi penggajian karyawan ini dengan tujuan untuk memberikan gambar PT.Evershine Convertindo dalam mengontrol 
keseluruhan aktivitas dan kinerja sumber daya manusia dengan harapan mempermudah perusahaan dalam memproses gaji karyawan dengan cepat, tepat dan efisien.

\section{Metodologi Penelitian}

\section{Teknik Pengumpulan data}

\section{A. Observasi}

Pengumpulan data dengan pengamatan langsung ke lokasi penelitian yaitu PT. Evershine Convertindo, guna mendapatkan informasi secara langsung.

\section{B. Wawancara}

Melakukan wawancara langsung dengan HRD untuk memperoleh data tentang penggajian pada PT.Evershine Convertindo.

\section{Studi Pustaka}

Melakukan dengan cara membaca, mengutip dan mencatat yang bersumber pada bahan -bahan pustaka yang mendukung dan berkaitan dengan penggajian. Selanjutnya dengan cara mempelajari dan memahami sistem yang berhubungan dengan masalah yang akan dibahas dalam pembuatan skripsi ini. Hal ini dimaksudkan agar penulis memiliki landasan teori yang kuat dalam menarik kesimpulan.

\section{Metode Pengembangan Sistem}

Model waterfall adalah suatu metodologi pengembangan peraangkat lunak yang mengusulkan pendekatan kepada perangkat lunak sistematik dan sekuensial yang mulai pada tingkat kemajuan sistem pada seluruh analisis, desain, kode, pengujian dan pemeliharaan.

\section{A. Analisa Kebutuhan Sistem}

Pada tahapan ini penulis melakukan analisa dengan melakukan observasi dan dari hasil observasi diperoleh kebutuhan-kebutuhan yang diperlukan dalam penelitian ini. Data yang dibutuhkan seperti data karyawan, data absensi, pembuatan rekap servis khusus bagian teknisi, penghitungan gaji, pembuatan laporan keuangan penggajian untuk dilaporkan kepada pemilik, dan pencetakan slip gaji yang akan dibagikan kepada karyawan. Sedangkan penulis menggunakan sublime dalam pengembangan perangkat lunak dengan sistem database menggunakan MySQL.

\section{B. Desain}

Proses ini fokus pada desain pembuatan sistem informasi penggajian karyawan. Perancangan dimulai dari tahap Unified Modeling Language (UML). Adapun diagram yang digunakan yaitu : Use Case Diagram, Activity Diagram, Sequence Diagram. Dilanjutkan dengan merancang basis data (database) menggunkan ERD (Entity Relationship Diagram), spesifikasi file, dan User Interface.

\section{Code Generation}

Desain harus selerasikan kedalam program perangkat lunak. Pada tahap ini penerjemah data atau pemecah masalah yang sudah dirancang kedalam bahasa pemrograman.

D. Testing

Pengujian fokus pada perangkat lunak secara dari segi lojik dan fungsional dan memastikan bahwa semua bagian sudah diuji. Hal ini dilakukan untuk meminimalisir kesalahan (eror) dan memastikan keluaran yang dihasilkan sesuai dengan yang diinginkan.

E. Support

Setelah aplikasi dibuat, dibutuhkan instalasi pada setiap clien. Selain itu perawatan komputer juga dibutuhkan seperti instalasi anti virus, penghapusan dokumen (sampah) pada recycle bin, uninstall program yang tidak dibutuhkan, meminimalkan program yang berjalan pada startup saat menjalakan program aplikasi penggajian.

\section{HASIL DAN PEMBAHASAN}

\subsection{Analisa Kebutuhan Software}

Dalam perancangan sistem maka peneliti melakukan kebutuhan software untuk dapat mengetahui proses yang terjadi dan menemukan masalah-masalah yang terjadi dalam suatu sistem. Adapun analisa kebutuhan software di PT. Evershine Convertindo sebagai berikut :

\section{A. Tahapan Analisa}

1. Halaman Depan :

A.1. Sistem mempunyai keamanan autentifikasi user.

2. Halaman Keuangan :

B.1. Keuangan dapat melakukan login.

B.2. Keuangan dapat melihat Halama Utama

(Dashboard), serta mengolahnya.

B.3. Keuangan dapat menambahkan Data Karyawan, serta mengolahnya.

B.4. Keuangan dapat menambahkan Data Jabatan, serta mengolahnya.

B.5. Keuangan dapat menambahkan Data

Tunjangan, serta mengolahnya.

B.6. Keuangan dapat menambahkan Data Gaji

Pokok, serta mengolahnya.

B.7. Keuangan dapat menambahkan Data

Kehadiran, serta mengolahnya.

B.8. Keuangan dapat menambahkan Data, serta mengolahnya.

B.9. Keuangan dapat menambahkan Laporan Penggajian, serta mengolahnya. 
B.

\section{Diagram}

Use case Bekerja dengan cara mendeskripsikan tipikal interaksi antar pengguna dengan sebuah sistem melalui sebuah cerita bagaimana sistem tersbut dipakai.

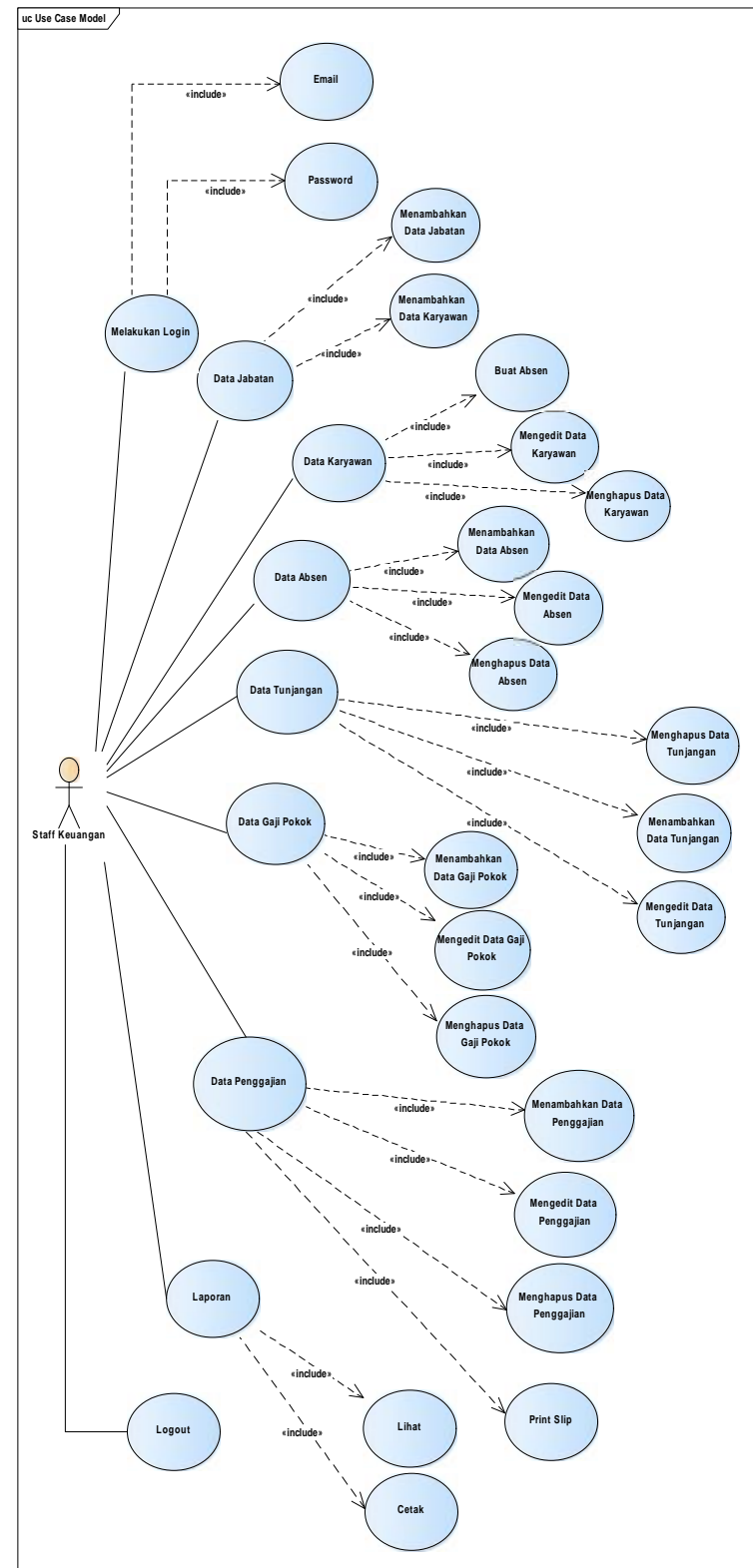

Sumber : Hasil Penelitian (2019)

Gambar 1. Rancangan Usecase

C.

Diagram

Activity diagram menggambarkan berbagai alur aktivitas dalam sistem yang sedang dirancang, bagaimana masingmasing alur berawal, decisioan yang mungkin terjadi dan bagaimana berakhir.

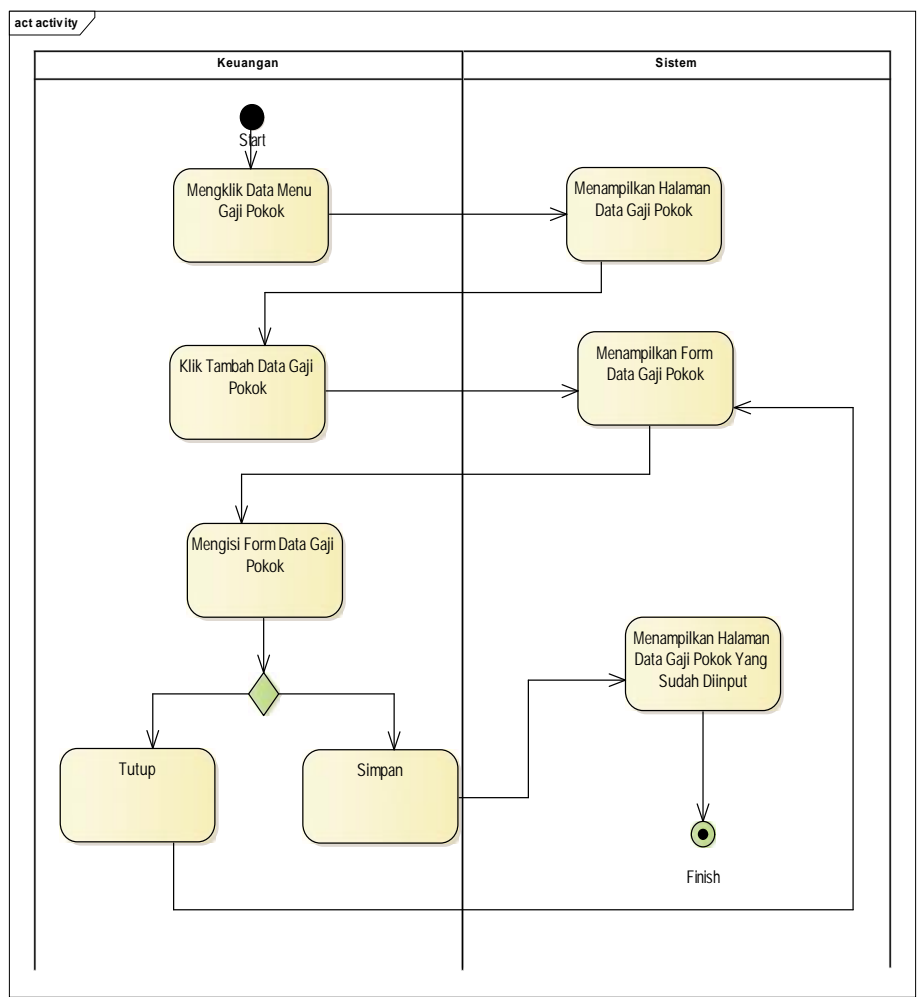

Sumber : Hasil Penelitian (2019)

Gambar 2. Activity Penggajian Karyawan

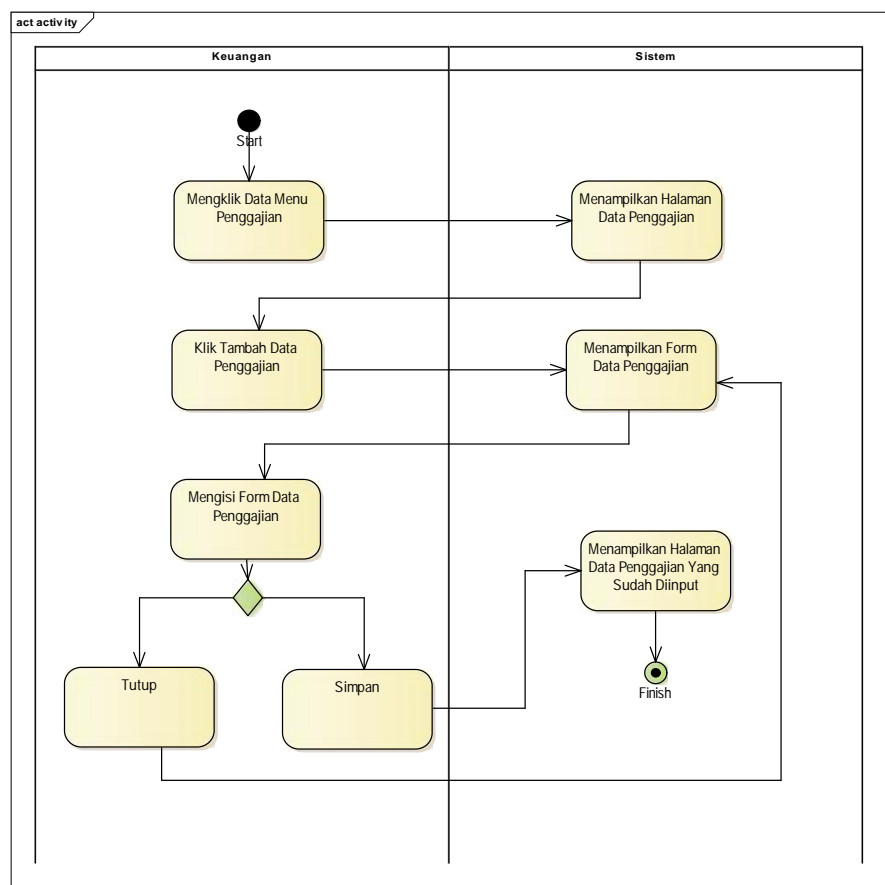

Sumber : Hasil Penelitian (2019)

Gambar 3 Activity Penggajian Karyawan 


\subsection{Desain}

Pada tahapan ini akan menjelaskan tentang desain database, desain software architecture dan desain interface dari sistem yang sedang dibuat.

\section{Database}

A. Entity Relationship Diagram

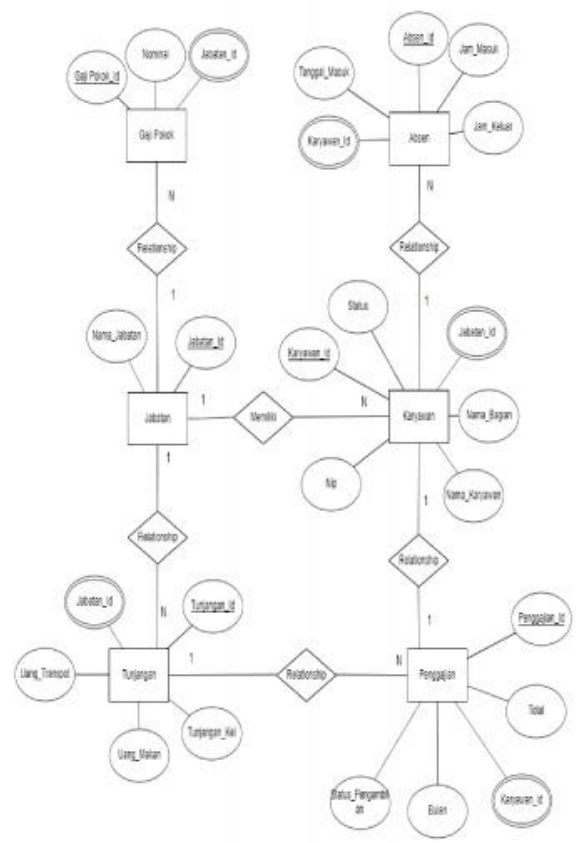

Sumber : Hasil penelitian (2019)

Gambar 4. Entity Relationship Diagram

\section{B. LOGICAL RECORD STRUCTURE}

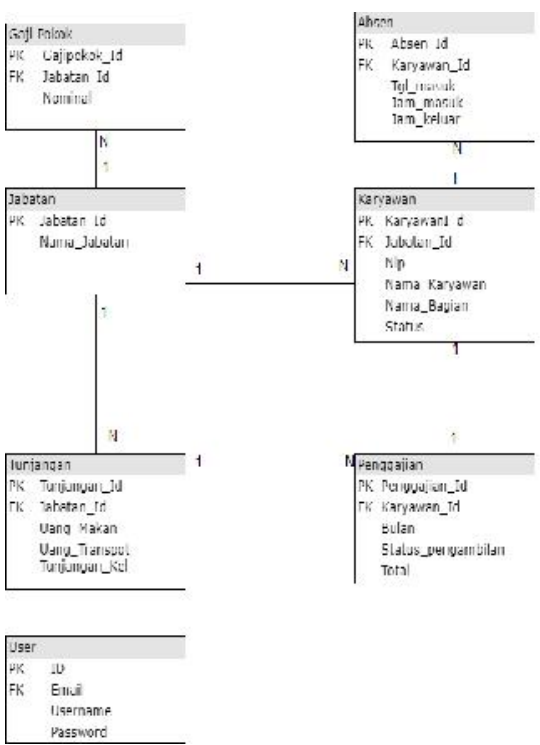

Sumber : Hasil Penelitian (2019)

Gambar 5. Logical Relationship Structure

\subsection{Implementasi}

Pengembangan dari perancangan yang telah dibuat untuk diterjemahkan menjadi kumpulan kode dan fungsi menggunakan bahasa pemrograman tertentu sehingga tercipta sistem informasi berbasis web yang telah dirancang.

1. Tampilan Halaman Depan

\section{PT. Evershine Convertindo}

Sumber : Hasil penelitian (2019)

Gambar 6. Halaman Tampilan Depan

2. Tampilan Halaman Login

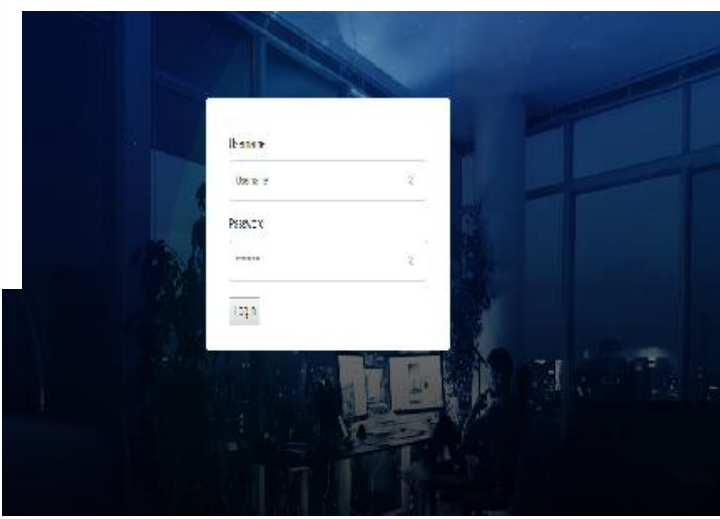

Sumber : Hasil penelitian (2019)

Gambar 7. Halaman Tampilan Login

3. Tampilan Halaman Jabatan

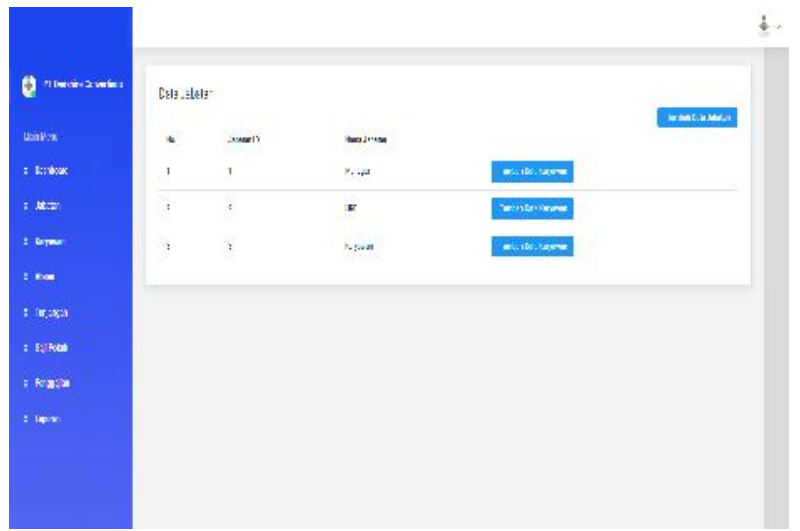


Sumber : Hasil penelitian (2019)

Gambar 8. Halaman Tampilan Jabatan

4. Tampilan Halaman Karyawan

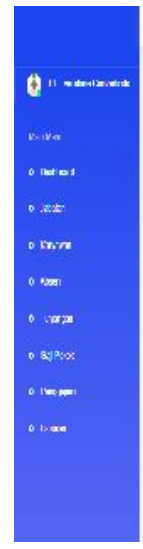

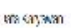

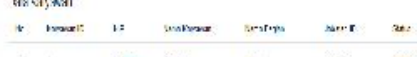

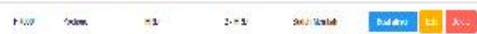

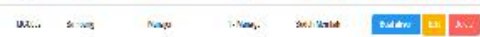

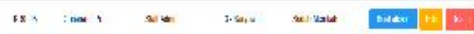

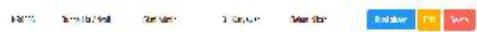

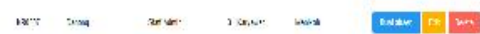

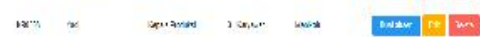

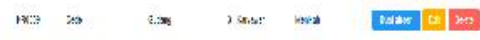

Sumber : Hasil penelitian (2019)

Gambar 9. Halaman Tampilan Karyawan

5. Tampilan Halaman Absen
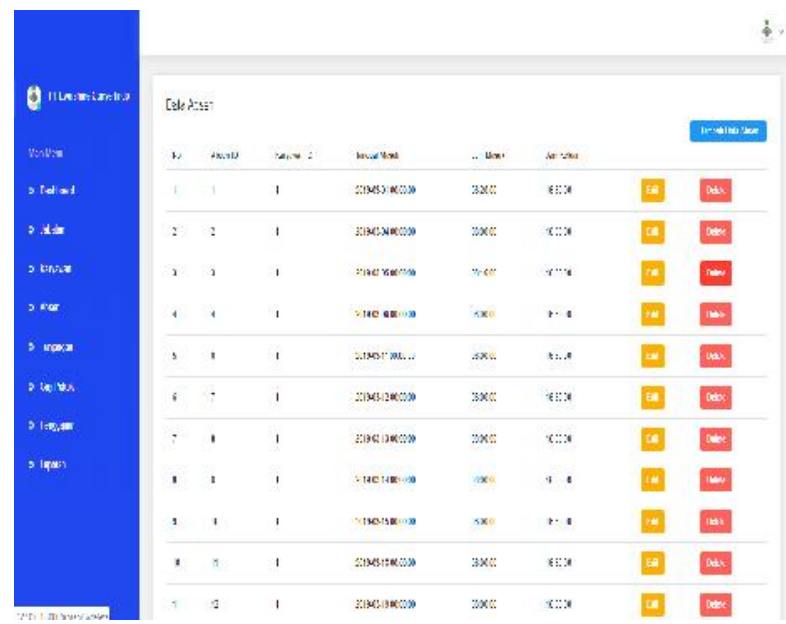

Sumber : Hasil penelitian (2019)

Gambar 10. Halaman Tampilan Absen

6. Tampilan Halaman Tunjangan

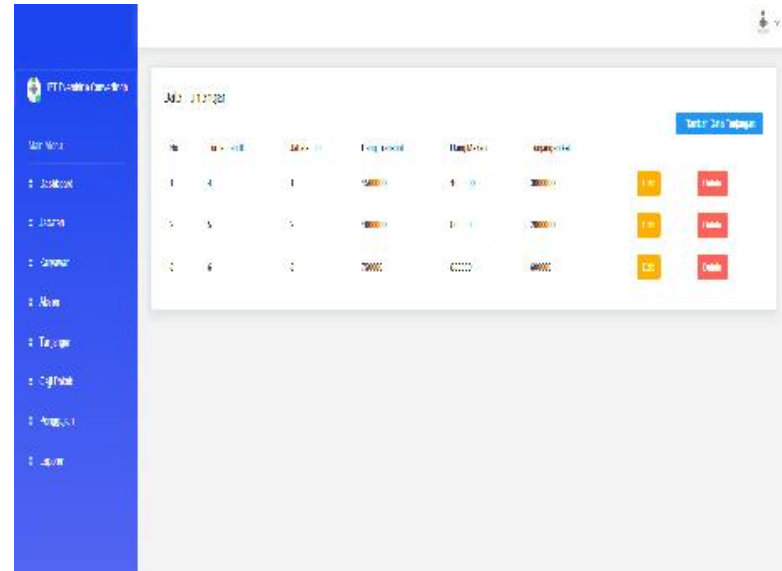

Sumber : Hasil penelitian (2019)

Gambar 11. Halaman Tampilan Tunjangan

7. Tampilan Halaman Gaji Pokok

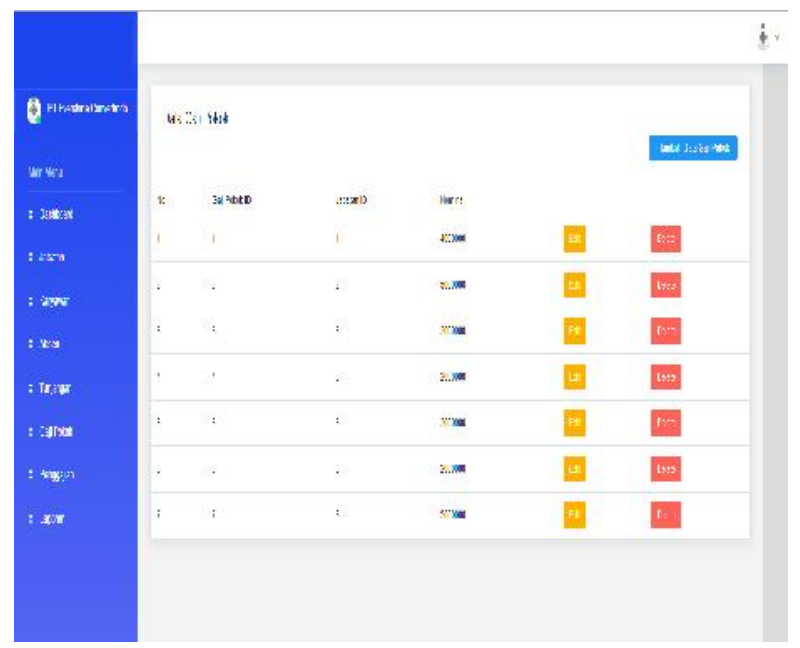

Sumber : Hasil penelitian (2019)

Gambar 12. Halaman Tampilan Gaji Pokok

8. Tampilan Halaman Penggajian

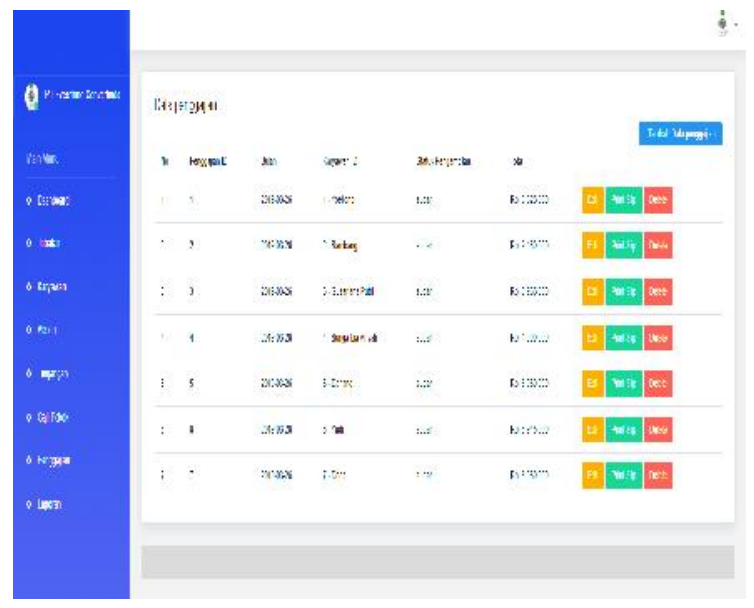


Sumber : Hasil penelitian (2019)

Gambar 13. Halaman Tampilan Penggajian

9. Tampilan Halaman Laporan

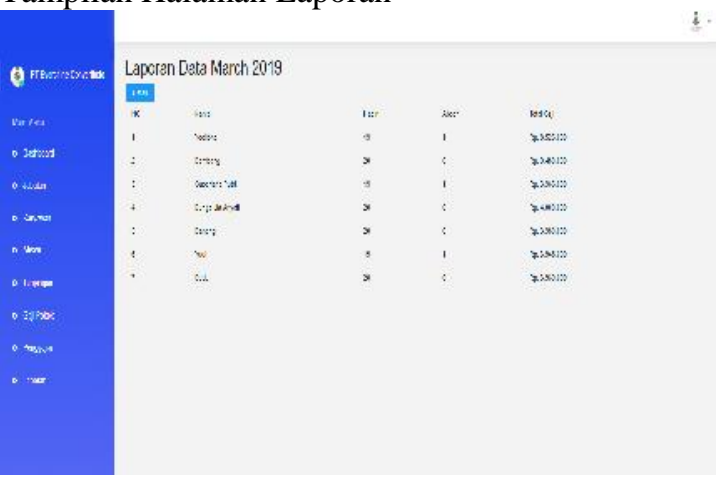

Sumber : Hasil penelitian (2019)

Gambar 14. Halaman Tampilan Laporan

\section{KESIMPULAN}

Berdasarkan hasil sistem informasi penggajian di PT.

Evershine Convertindo, maka kesimpulannya adalah:

1. Sistem Informasi Penggajian Karyawan dapat membantu dalam pengelolaan penggajian karyawan sehingga informasi yang valid.

2. Dengan diterapkan sistem ini diharapkan segala kendala tentang keterlambatan dan ketidak akurat laporan-laporan yang berhubungan dengan masalah penggajian karyawan dapat diatasi.

3. Hasil rancangan sistem dapat didesain dengan multi user sesuai dengan hak akses yang diberikan.

\section{REFERENSI}

[1] Abdulloh, R. (2018a). 7 in 1 Pemrograman Web Tingkat lanjut. (Abdulloh Rohi, Ed.). jakarta.

[2] Anggraeni, E. Y., \& Irviani, R. (2017a). Pengantar Sistem Informasi. (E. Risantio, Ed.). Yogyakarta.

[3] Dalis, S., Nurmah, S., \& Purwanto, H. (2019). Pemanfaatan Model View Controller, 7(1), 35-42.

[4] Entas, S., \& Alawiah, E. T. (2015). Sniptek 2014 Isbn : 978-602-72850-5-7 Perancangan Sistem Usulan Program Penggajian Isbn : 978-602-72850-5 -7, 1-4.

[5] Enterprise, J. (2017). PHP Komplet. Jakarta: Pt. Elex Media Komputindo, Jakarta.
[6] Heryanto, A., Fuad, H., Dananggi, D., Stmik, D., Sarana, B., Stmik, M., \& Sarana, B. (2014). Rancang bangun aplikasi sistem informasi, 4(2), 2-5.

[7] Jumardi, R. (2019). website statis konsep dan praktik HTML-CSS. (M. P. Ralmugiz Uke, S.Si., Ed.). Ponorogo: Uwais Inspirasi Indonesia.

[8] Komalasari, A., \& Fauziah, S. (2018). Sistem Informasi Akuntansi Penggajian Karyawan Dalam Usaha Meningkatkan Pengendalian Intern Perusahaan, 2-10.

[9] Maharani, M. A. (2018). Analisa dan Perancangan Sistem Informasi dengan Codeigniter dan Laravel. (Hakim Lukmanul, Ed.) (cetakan pe). Yogyakarta: Cv. Lokomedia.

[10] Mahatmyo, A. (2019). Sistem Informasi Akutansi Suatu Pengantar. Yogyakarta: Cv Budi Utama.

[11] Mania, M., Purnama, B. E., \& Sukadi. (2016). Sistem Informasi Penggajian Karyawan Mitra Karya Prima Di Pembangkit Listrik Tenaga Uap 1 Pacitan. IJSE Indonesian Journal on Software Engineering, 2(1), 3943. Retrieved from http://ejournal.bsi.ac.id/jurnal/index.php/ijse/article/vie w/600/491

[12] Mayasari, M. S. (2015). Analisa dan perancangan aplikasi sistem informasi penggajian karyawan pada pt . Aditya buana inter sungailiat bangka, 6(2), 277-288.

[13] Mulyani, S. (2016). Metode Analisis dan Perancangan Sistem. bandung: Abdi Sistematika.

[14] Nasional, J., Informasi, S., Eko, C., Eka, J., \& Gunawan, F. E. (2017). Perancangan Sistem Informasi Penggajian Terintegrasi Berbasis Web ( Studi Kasus di Rumah Sakit St . Elisabeth ), 2, 225-232.

[15] Nugroho, B. (2019). Aplikasi Pemrograman Web Dinamis dengan PHP dan MySQL. Yogyakarta: Gava Media.

[16] Prasetyo, F. (2015). Uji Coba Sistem Informasi Penggajian Guru Berbasis Web Pada Smk Tamansiswa Cikampek.

[17] Rerung, R. R. (2018). Pemrograman Web Dasar. Yogyakarta: CV BUDI UTAMA.

[18] Rusman, A., \& Angraini, S. L. (2019). Penerapan Extreme Programming Pada Sistem Informasi 
[19] Saryoko, A. (2015). Montessori Private School.

[20] Somya, R. dan Nathanael, T. M. E. (2019). Pengembangan Sistem Informasi Pelatihan Berbasis Web Menggunakan Teknologi Web Service Dan Framework Laravel, 16(1), 51-58.

[21] Utara, B. (2014). Sniptek 2014 Perancangan Program Aplikasi Penggajian Karyawan Pada Isbn: 978-60272850-5-7 Seminar Nasional Ilmu Pengetahuan dan Teknologi Komputer Nusa Mandiri, 404-409.

[22] Wicaksono, S. R. (2017). Rekayasa Perangkat Lunak. Jakarta: Seribu Bintang. 